\title{
Bentuk dan Makna Lagu Ida Sang Sujati Karya I Komang Darmayuda
}

\author{
Alfin Syahrian ${ }^{1}$, Ricky Irawan ${ }^{2}$, Agustinus Sani Aryanto $^{3}$ \\ ${ }^{123}$ Program Studi Musik, Fakultas Seni Pertunjukan, \\ Institut Seni Indonesia Denpasar \\ email: ${ }^{1}$ alfinsyahrian@gmail.com, ${ }^{2}$ rickyirawan@isi-dps.ac.id, \\ 3agustinussani@isi-dps.ac.id
}

\begin{abstract}
The Balinese song Ida Sang Sujati (2016) performed by Bali Kumara singers was inspired by a moment when its composer I Komang Darmayuda was appointed as a music judge at Pesta Kesenian Bali (PKB) which located at Ardha Candra Open Stage. He was stunned by the idea of the parade and the venue for the event which was being made for the governor of Bali Prof. Ida Bagus Mantra who served in 1978-1988. The problems of this research are (1) the musical form of the Balinese song Ida Sang Sujati by I Komang Darmayuda, (2) the process of making the Balinese song Ida Sang Sujati by I Komang Darmayuda, (3) the musical meaning contained in the Balinese song Ida Sang Sujati by I Komang Darmayuda. The method that being used for this research is qualitative, with data collection techniques through interviews, observation, documentation. The theory used to explore the problem is the theory of song form and structure analysis and the theory of meaning. Primary data sources were obtained from interviews and observations. Secondary data were obtained from books, journals, and internet sources.
\end{abstract}

Keywords: form of song, Ida Sang Sujati, musical meaning.

\begin{abstract}
ABSTRAK
Lagu Bali Ida Sang Sujati (2016) yang dibawakan oleh penyanyi Bali Kumara yang terinspirasi saat penciptanya I Komang Darmayuda ditunjuk sebagai juri di ajang Pesta Kesenian Bali (PKB) yang berlokasi di Gedung Terbuka Ardha Candra. Beliau tertegun akan hasil gagasan dari ajang parade dan tempat kesenian tersebut oleh gubernur Bali yang sangat menginspirasi menjabat pada tahun 1978-1988 yaitu Prof. Ida Bagus Mantra. Permasalahan penelitian ini adalah (1) bentuk musikal lagu Bali Ida Sang Sujati karya I Komang Darmayuda (2) proses pembuatan lagu Bali Ida Sang Sujati karya I Komang Darmayuda (3) makna musikal yang terkandung pada lagu Bali Ida Sang Sujati karya I Komang Darmayuda. Metode penelitian yang digunakan adalah kualitatif, dengan teknik pengumpulan data melalui wawancara, observasi, dokumentasi. Teori yang digunakan untuk mengupas permasalahan adalah teori analisis bentuk dan struktur lagu serta teori makna. Sumber data primer diperoleh dari hasil wawancara, dan pengamatan. Data sekunder diperoleh dari sumber buku, jurnal, dan internet.
\end{abstract}

Kata kunci : bentuk lagu, Ida Sang Sujati, makna musikal. 


\section{PENDAHULUAN}

Di era milenial anak-anak dan remaja menikmati teknologi dengan segala kemudahannya. Dalam hal musik itu juga berarti kemudahan akses pada berbagai jenis dan genre musik yang ada di seluruh dunia. Aktifitas mendengarkan musik saat ini tidak hanya ditawarkan melalui pertunjukan musik live, namun juga yang diperluas melalui rekaman abaik audio maupun video. Untuk menyebut beberapa nama misalnya Youtube, JOOX, Spotify, Sound Cloud, Apple Music dan lain-lainnya. Sarana tersebut menyediakan banyak pilihan. Termasuk di dalamnya musik populer yang hits baik nasional dan internasional.

Perkembangan budaya musik populer saat ini seringkali mengadopsi letarbelakang kulturalnya masing-masing untuk kemudian menjadi gramatikal musik baru. Fenomena akulturatif pada musik semacam ini semakin Meningkat. Terutama pada musik pop yang ada di Bali. (Ardini, 2018).

Budaya musik tradisi Bali dan budaya musik barat kerap dipadukan dan kemudian dikembangkan menjadi sesuatu yang bermakna baru. Pilihan pemaduan itu salah satunya ada pada aspek kebahasaan. Lagu-lagu berbahasa Bali, khususnya lagu-lagu rakyat seperti gegendingan pada masa lalu di produksi kembali dengan menggunakan gramatikal musik barat. Lagu-lagu rakyat semacam itu, khususnya lagu anak-anak yang kurang mendapat perhatian dan terpinggirkan diolah kembali dengan kemasan musik yang baru.

Anak-anak dan remaja saat ini cenderung lebih tertarik dengan budaya asing dan menganggap bahwa budaya lokal mereka kuno dan sudah ketinggalan jaman (Asty, 2017 : 102). Sebagai gantinya mereka bangga jika dapat menyanyikan lagulagu populer kekinian daripada menyanyikan lagu dari daerah sendiri. Seperti yang dikemukakan oleh Ardjana (1999: 1), bahwa anak-anak jaman sekarang memang benar-benar telah diracuni oleh peradaban baru yang super canggih dan modern. Kemajuan teknologi mengakibatkan terjadinya perubahan sosial masyarakat. Anakanak semakin tidak mengenal budaya sendiri. Apalagi ditambah unsur budaya Bali yang mengalami dampak arus globalisasi yaitu bahasa mendapatkan pengaruh yang signifikan dari perkembangan teknologi (Giri, 2017 Volume 1 No.1). Setia (dalam Giri, 2017 Volume 1 No.1) juga memaparkan muncul ke khawatiran bahasa Bali semakin dijauhi dalam dunia pergaulan sehari-hari masyarakat Bali. Bahkan lebih ekstrem dikatakan bahwa bahasa Bali akan mati pada tahun 2041. Dalam konteks 
semacam inilah lagu-lagu anak berbahasa Bali dapat memainkan peranan penting. Salah satu usaha yang dapat dilakukan untuk mempertahankan budaya Bali melalui lagu-lagu daerah untuk anak-anak.

Berdasarkan pemikiran di atas, I Komang Darmayuda, salah seorang penulis lagu Bali mendirikan sanggar Griya Musika Sukawati Cressendo. Berbagai cara ia lakukan untuk ikut andil dalam pelestarian budaya Bali melalui musik. Yang patut dicatat dari upaya itu adalah pembuatan album Bali Kumara sebagai salah satu alternatif agar masyarakat dapat mencintai tradisi Bali kepada anak-anak sebagai penerus bangsa. Dengan begitu anak-anak akan lebih mengenal tradisi Bali.

Bali Kumara memiliki visi dan misi berkontribusi melestarikan budaya dan bahasa Bali dalam bentuk lagu Bali. Cara itu dinilai dapat menumbuhkan kecintaan terhadap seni dan budaya daerah khususnya lagu-lagu daerah Bali di kalangan anak-anak dan juga ikut berperan serta dalam melestarikan Bahasa Bali. Sebagai pendiri, Komang Darmayuda tidak hanya terlibat membimbing anak-anak didiknya dalam olah vokal, namun juga yang menciptakan sebagian besar lagu-lagu pada Album Bali Kumara. Lagu-lagu yang ia tulis bukan sekedar lagu. Tapi yang juga beperan mengajak anak-anak Bali untuk memahami kearifan lokal dari tata krama, sopan santun, sejarah, jiwa orang Bali, dan toleransi (Hasil wawancara dengan I Komang Darmayuda 22 Mei 2019).

Ida Sang Sujati adalah salah satu nilai dalam kebudayaan Bali yang tidak lagi difahami oleh generasi muda di Bali. Lewat konsep ini, Komang Darmayudha mensosialisasikannya lewat lagu-lagu pada album Bali Kumara. Ida Sang Sujati secara umum menceritakan tentang kepemimpinan gubernur Bali pertama yaitu Prof. Ida Bagus Mantra. Lahir di Badung (sekarang Denpasar), Bali 8 Mei 1928 meninggal 10 Juli 1995. Menurut Komang Darmayuda lagu ini merepresentasikan ketokohan dari Ida Bagus Mantra. Gubernur Bali yang juga pernah menjabat sebagai duta besar Indonesia untuk India ini adalah pelaku sejarah yang sangat berpengaruh di Bali. Lagu berbahasa Bali ini mempunyai makna yang dalam dan kuat akan kepemimpinan terhadap tokoh budayawan besar yang sangat menginsipirasi ditahun 80-an membangun fisik maupun pembangunan mental identitas masyarakat Bali.

Selain itu, lirik lagu Bali Ida Sang Sujati mengandung nilai estetis dan kearifan lokal Bali. Ida Sang Sujati sebagai salah satu contoh lagu berbahasa Bali 
yang tidak hanya mengedepankan aspek hiburan semata, namun aspek pendidikan dan desiminasi nilai-nilai luhur budaya Bali.

\section{METODE PENELITIAN}

Penelitian ini menggunakan metode kualitatif. Data kualitatif adalah jenis data yang bersifat deskriptif berupa makna-makna atau ungkapan. Sumber data yang digunakan dalam penulisan terdiri dari data primer dan data sekunder. Data primer adalah bentuk pencarian sumber data dengan cara menentukan informan yang secara langsung diwawancarai, data sekunder adalah bentuk sumber data yang didapat dari beberapa sumber buku, jurnal dan dokumen yang relevan dengan penelitian.

Dalam hal tersebut penulis dalam pengumpulan data dengan menggunakan langkah-langkah untuk menemukan atau mencari data dan sumber terkait untuk menggali semua informasi, penulis menggunakan beberapa teknik yang dilakukan guna memenuhi semua data yang diperlukan, yaitu observasi dan wawancara dan studi dokumentasi.

\section{PEMBAHASAN}

\section{Eksistensi Lagu Ida Sang Sujati}

Lagu Ida Sang Sujati karya I Komang Darmayuda di launching pertama kalinya pada album Bali Kumara III yang digelar di Gedung Ksirarnawa pada tanggal 12 Desember 2016. Sejak pertama diperdengarkan hingga hari ini, lagu Ida Sang Sujati berkembang menjadi salah satu lagu pilihan dalam berbagai ajang perlombaan vokal di Bali.

Komang Darmayuda menjelaskan, lagu ini sengaja diciptakan sebagai upaya untuk turut melestarikan budaya Bali dalam kapasitasnya sebagai seorang pemusik. Penciptakan lagu sekaligus meluncurkan lagu terebut dalam album Bali Kumara III diharapkan dapat berperan sebagai salah satu alternatif agar masyarakat untuk dapat lebih mencintai tradisi Bali, khususnya anak-anak sebagai penerus kebudayaan Bali di masa depan.

\section{Ida Sang Sujati , Bali Kumara, dan Sanggar Seni Griya Musika Sukawati}

Bali Kumara merupakan kumpulan anak-anak yang tergabung dalam payung besar Sanggar Seni Griya Musika Sukawati "Cressendo" yang terbentuk di tahun 
2013. Sanggar ini memiliki misi untuk mengajegkan budaya Bali melalui lagu berbahasa Bali. Bali Kumara adalah strategi untuk melestarikan bahasa Bali itu sendiri, di tengah masifnya budaya global yang tumbuh subur di tengah-tengah kehidupan sehari-hari masyarakat Bali. Di sinilah Bali Kumara mengambil peran untuk mengedukasi dan mengingatkan masyarakat untuk tetap melestarikan bahasa Bali sebagai salah satu kearifan lokal ditengah-tengah arus globalisasi. Oleh sebab itu Komang Darmayuda dalam berbagai lagunya, sengaja menggunakan basa singgih (bahasa Bali halus) termasuk dalam lirik-lirik lagu album Bali Kumara.

\section{Analisis Bentuk Lagu Ida Sang Sujati I Komang Darmayuda}

Djelantik (1990 : 18) mengatakan bahwa dalam semua jenis kesenian, baik yang visual maupun auditif yang dapat dinikmati oleh kita, mengandung dua unsur mendasar, yakni Bentuk (form) dan Susunan (struktur). Searah dengan itu, menurut Prier (1996: 5) bentuk karya musik dibedakan menjadi tiga bentuk, yang pertama bentuk lagu satu bagian: dengan satu kalimat, bentuk lagu dua bagian: dengan dua kalimat yang berlainan, dan yang ketiga bentuk lagu tiga bagian: dengan tiga kalimat yang berlainan. Banoe (2003: 151) juga mengklasifikasikan bahwa bentuk musik berdasarkan susunan rangka lagu ditentukan menurut bagian-bagian kalimatnya.

Berdasarkan pendapat tersebut, pembahasan tentang bentuk lagu Ida Sang Sujati ini tergolong dalam bentuk lagu tiga bagian yaitu A A' B.

1. Introduksi

Introduksi adalah pengantar musik pengiring vokal atau pembukaan dengan intro (introduksi) sebelum masuk suara vokal (Banoe, 2003: 197). Introduksi pada lagu Ida Sang Sujati dapat dilihat pada gambar berikut.

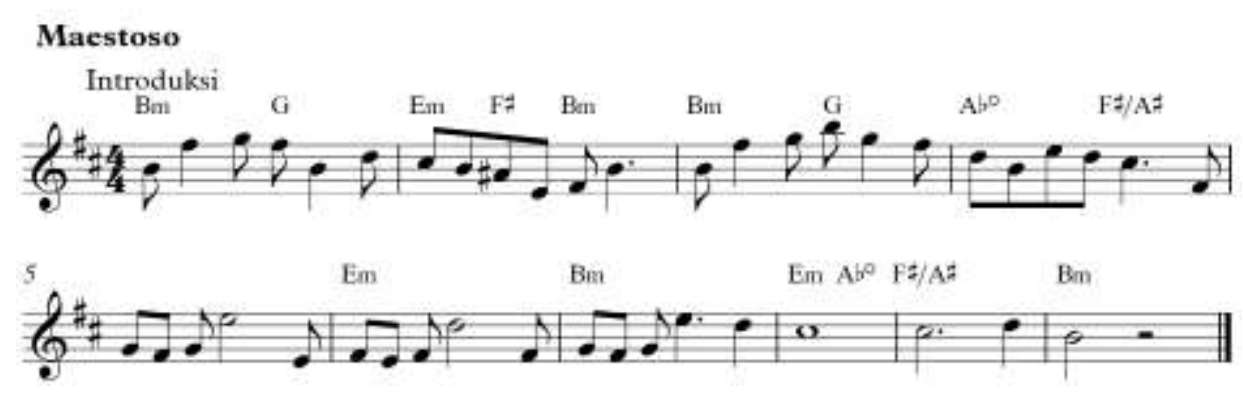

Notasi 1: Introduksi 
Pada introduksi ini dimainkan dengan nada dasar $\mathrm{B}=$ la karena menyesuaikan dengan penyanyi Bali Kumara Nita Purnama Sari, lagu Ida Sang Sujati di awali dengan suasana minor atau akord minor adapun sukat dengan 4/4 yang merupakan dalam satu birama terdiri dari 4 ketukan. Tempo yang dipakai yaitu Maestoso (70MM) yang berarti layak atau anggun adalah istilah dalam musik yang menyatakan lambat tetapi sifatnya penuh keagungan. Kemudian introduksi pada komposisi ini diawali dengan suara instrumen gangsa yang menggunakan midi pada sesi rekaman. Progress chord yang dipakai dapat dilihat pada gambar berikut :

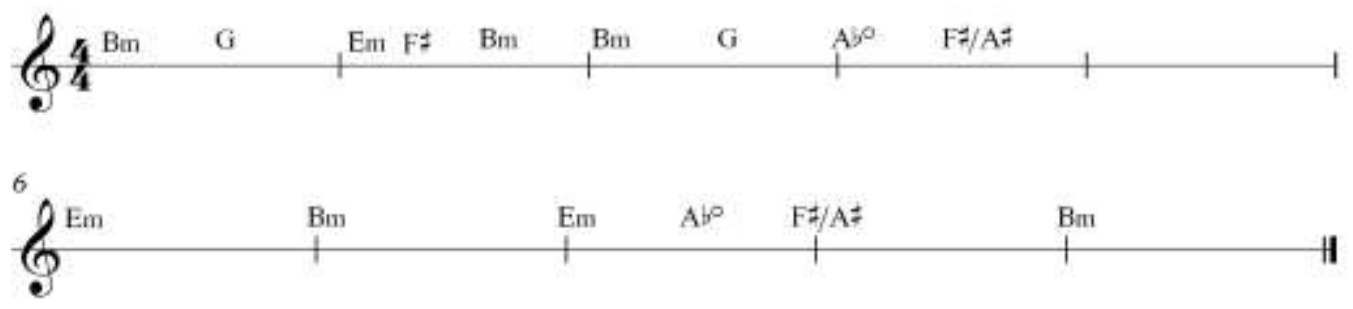

Notasi 2: Progress chord introduksi.

Gambar di atas menunjukan bahwa, dalam satu birama terdiri dari 1 sampai 3 chord, yang dimulai dari akord enam atau minor.

\section{Bagian A}

Bagian A adalah periode yang terdiri dari dua frase, frase tanya (anteseden) dan frase jawab (konsekuen). Periode adalah sejumlah ruang birama (biasanya 8 atau 16 birama) yang merupakan satu kesatuan. Untuk memperlihatkan struktur musik, maka ilmu bentuk memakai sejumlah kode. Untuk kalimat atau periode umumnya dipakai huruf besar (A, B, C dsb). Bila sebuah kalimat atau periode diulang dengan disertai perubahan, maka huruf besar disertai tanda aksen (') misalnya A B A' (Prier, 1996 : 2). Progress chord pada bagian ini dilihat pada gambar berikut :

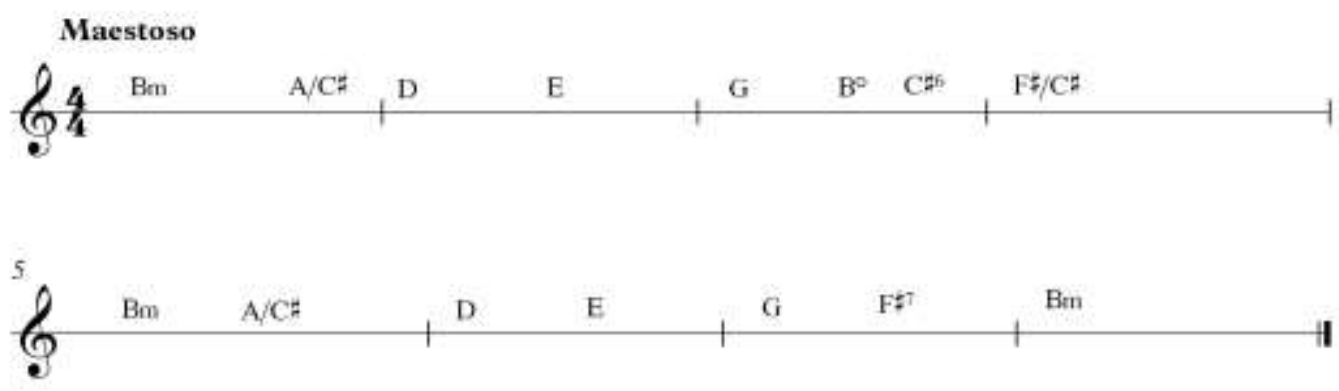

Notasi 3: Progress chord bagian A. 
Untuk memperjelas keterangan periode bagian $A$, seperti frase tanya (anteseden) dan frase jawab (konsekuen) dapat dilihat gambar berikut :

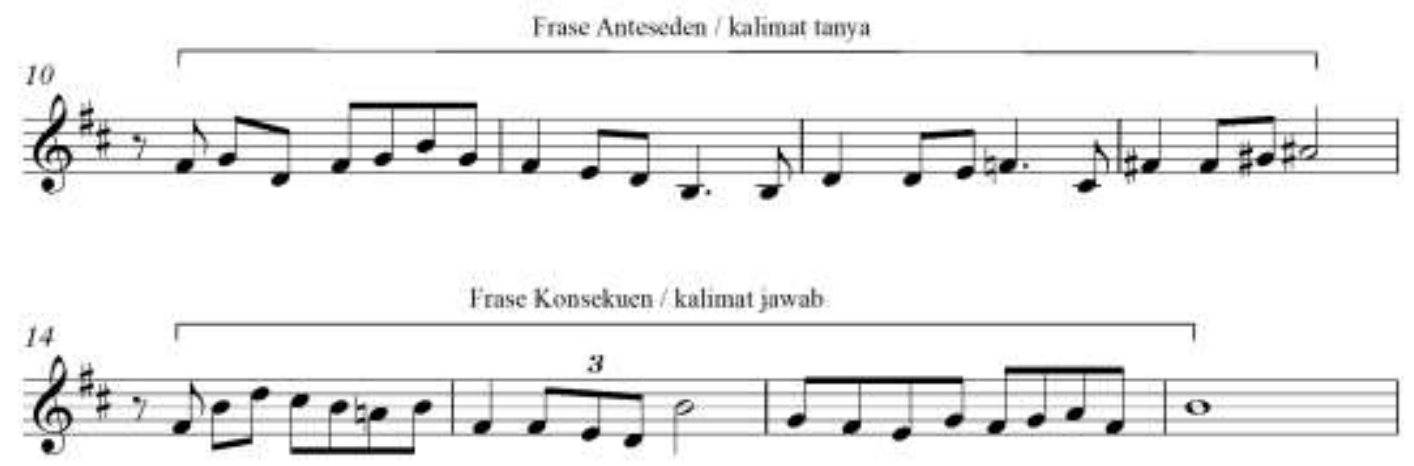

Notasi 4: Periode bagian A.

Bagian ini terdiri dari delapan birama, sesuai dengan pernyataan Prier bahwa periode adalah sejumlah ruang birama (biasanya 8 atau 16 birama) yang merupakan satu kesatuan. Bagian ini dimulai dari birama 10 sampai birama 17. Adapun bagian ini terdiri dari dua frase, frase anteseden dan frase konsekuen, untuk memperjelas keterangan pada bagian ini, dimulai dari frase anteseden :

\section{a. Frase Anteseden}

Frase pada bagian ini dimulai dari birama 10 sampai birama 13. Arti dari frase anteseden menurut Prier (1996: 2) sejumlah birama (biasanya 1-4 atau 1-8) disebut pertanyaan karena biasanya berhenti dengan nada yang mengambang, maka dapat dikatakan berhenti dengan koma. Sesuai dengan pernyataan tersebut, frase anteseden pada bagian ini sejumlah 4 birama. Untuk memperjelas keterangan frase anteseden dapat dilihat pada gambar berikut :

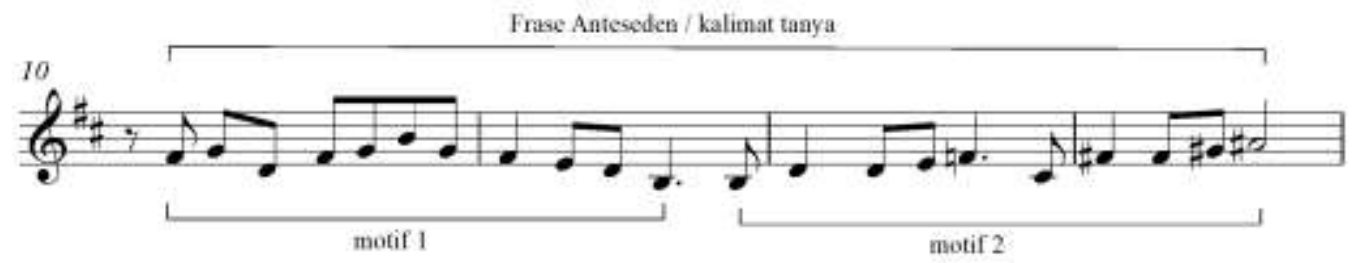

Notasi 5: Frase anteseden.

Motif di atas merupakan motif pembalikan (inversion), setiap interval naik kini dijadikan interval turun begitu juga sebaliknya setiap interval yang dalam motif asli menuju ke bawah dalam pembalikannya diarahkan ke atas (Prier, 1996 : 33). Untuk memperjelas motif pembalikan, dapat dilihat gambar berikut. 


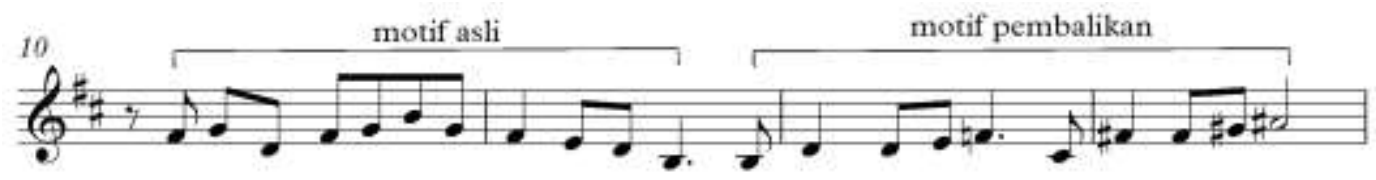

Notasi 6: Motif pembalikan (inversion).

Keterangan diatas menunjukkan bahwa, terdapat motif pembalikan pada motif ke dua Kemudian dilanjutkan dengan frase konsekuen.

\section{b. Frase Konsekuen}

Frase pada bagian ini dimulai dari birama 14 sampai birama 17, jumlah seluruhnya adalah 4 birama. Seperti pada frase anteseden, pada frase konsekuen juga terdiri dari dua budah motif. Bagian kedua dari kalimat (biasanya birama 5-8 atau 9-16) disebut jawaban atau kalimat belakang karena melanjutkan dari pertanyaan dan berhenti dengan titik atau akord tonika (Prier, 1996: 2). Untuk memperjelas keterangan frase konsekuen dapat dilihat gambar berikut :

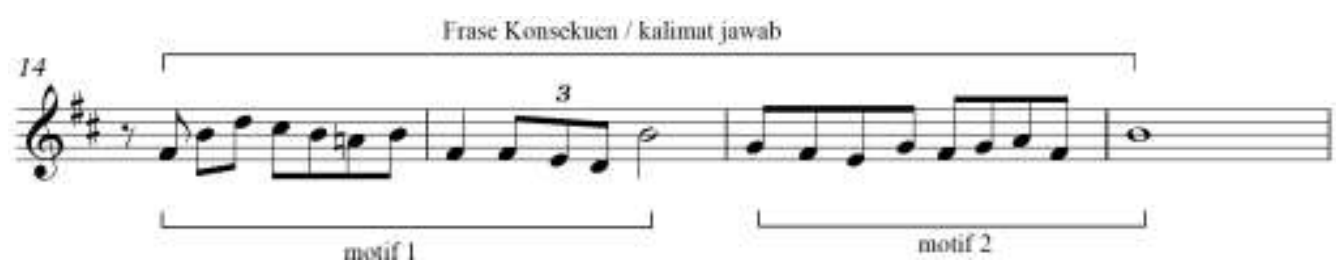

Notasi: Frase Konsekuen.

Gambar di atas menyatakan bahwa motif 1 merupakan pembalikan nada. Untuk memperjelas bahwa motif 1 merupakan motif pembalikan nada dapat dilihat gambar berikut. Setelah penjelasan tentang bagian $A$, kemudian akan dilanjutkan dengan bagian A'.

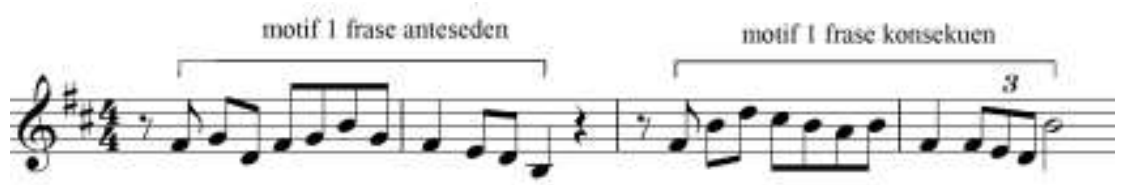

Notasi 8: Motif pembalikan (inversion)

3. Bagian A'

Bagian A' merupakan periode yang memiliki 2 frase yaitu frase anteseden dan frase konsekuen. Periode adalah sejumlah ruang birama (biasanya 8 atau 16 birama) yang merupakan satu kesatuan. Bagian ini merupakan repetisi dari bagian $A$ yang terdapat perubahan pada frase konsekuen. Bagian ini menggunakan sukat 4/4 dan progress chord yang dapat dilihat sebagai berikut: 


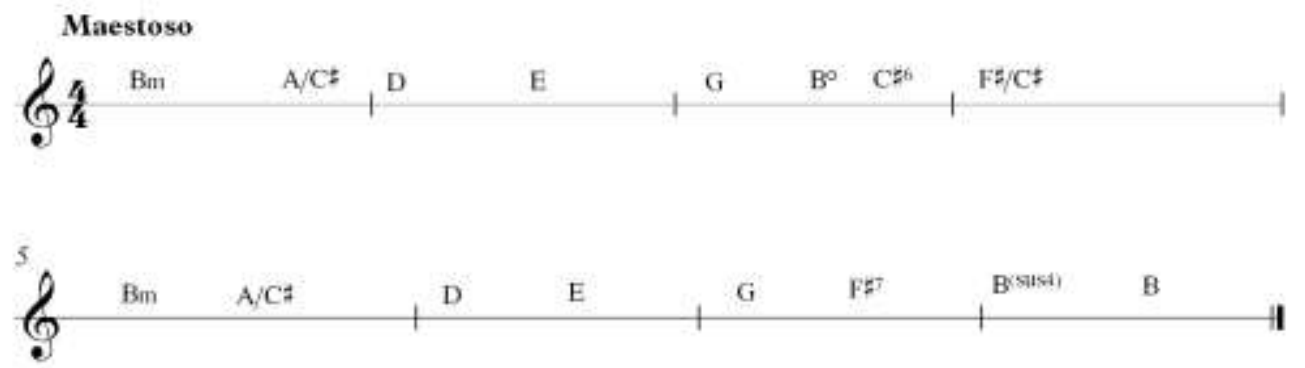

Notasi 9: Progress chord bagian A'.

Bagian ini terdiri dari dua frase yaitu frase anteseden dan frase konsekuen Untuk memperjelas keterangan frase pada bagian ini dapat dilihat pada gambar berikut.

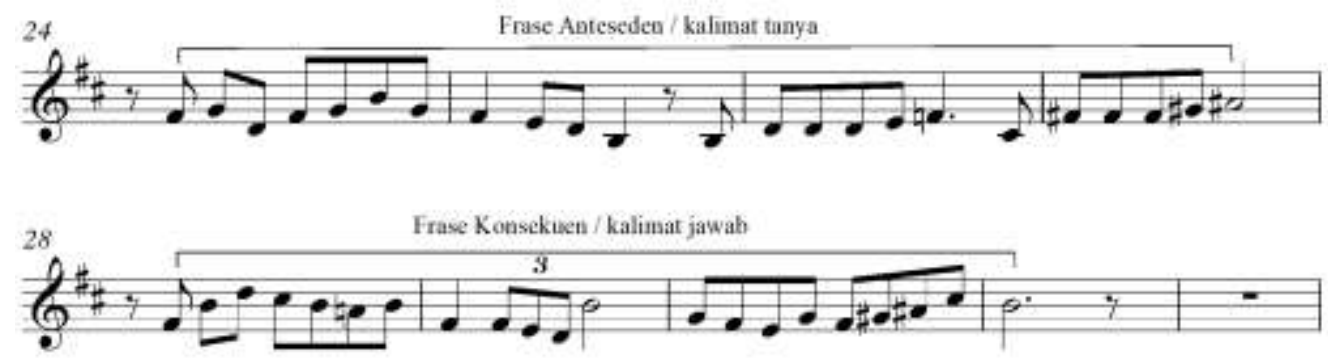

Notasi 10: Periode bagian A'.

Keterangan di atas menunjukkan bagian ini terdiri dari 8 birama, dari birama 24 sampai birama 31 yang terbentuk dari dua frase yaitu frase anteseden dan frase konsekuen.

\section{a. Frase Anteseden}

Frase tanya pada bentuk lagu bagian A' dimulai dari birama 24 hingga 31. Untuk memperjelas keterangan frase anteseden dapat dilihat gambar berikut.

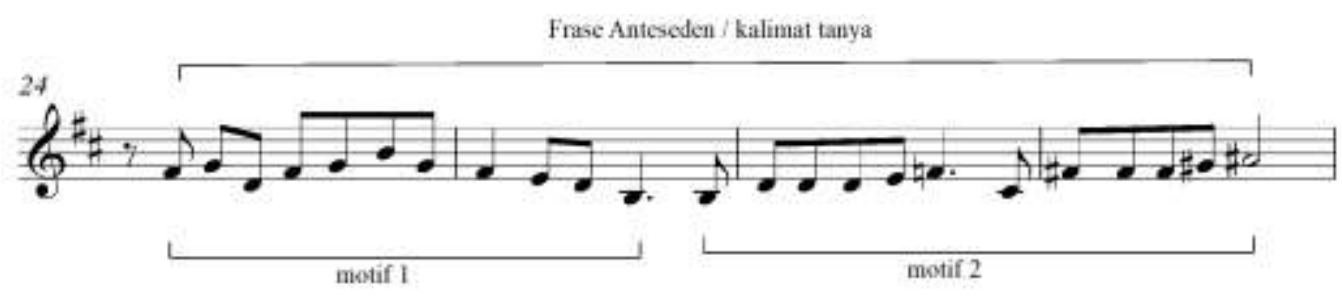

Notasi 11: Frase Anteseden.

Dari uraian di atas menunjukan bahwa, motif 1 frase anteseden ini merupakan repetisi dari motif 1 frase anteseden bagian A. Untuk memperjelas keterangan repetisi pada bagian ini dapat dilihat sebagai berikut. 


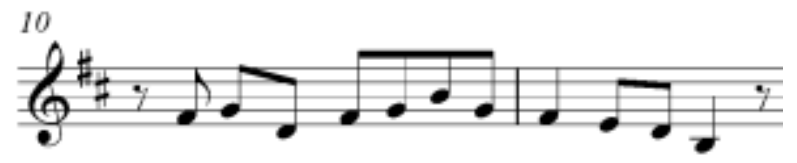

Gambar 12: Frase anteseden bagian $\mathrm{A}$.

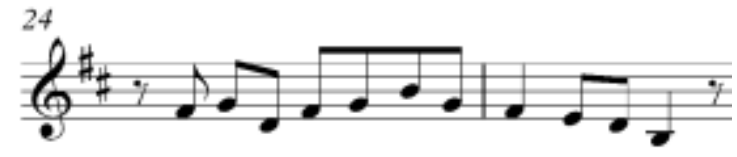

Notasi 13: Frase anteseden bagian A'.

Dengan pengulangan motif harafiah, yaitu untuk menegaskan suatu pesan (Prier, 1996: 27). Sedangkan pada motif 2 pada frase anteseden bagian A' adalah pemerkecilan nilai nada (diminuation of value) dari motif 2 frase anteseden. Untuk memperjelas keterangan pemerkecilan nilai nada (diminuation of value) dapat dilihat gambar berikut.

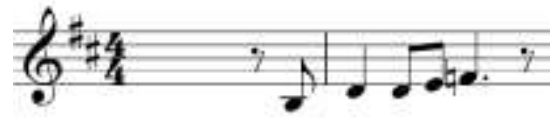

Notasi 14A: Motif 2 frase anteseden bagian A

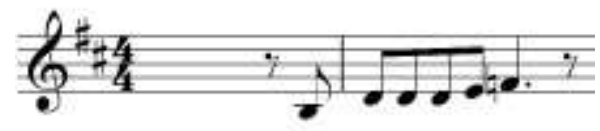

Notasi 14 B: Motif 2 frase anteseden bagian A'

Dapat disimpulkan bahwa motif 2 frase anteseden bagian A' merupakan motif pemerkecilan nada (diminuation of value). Kemudian dilanjutkan dengan frase Konsekuen bagian A' sebagai berikut.

b. Frase Konsekuen

Frase jawab pada bagian A' terdapat pada birama 28 sampai 31 . Untuk memperjelas keterangan frase konsekuen dapat dilihat sebagai berikut.

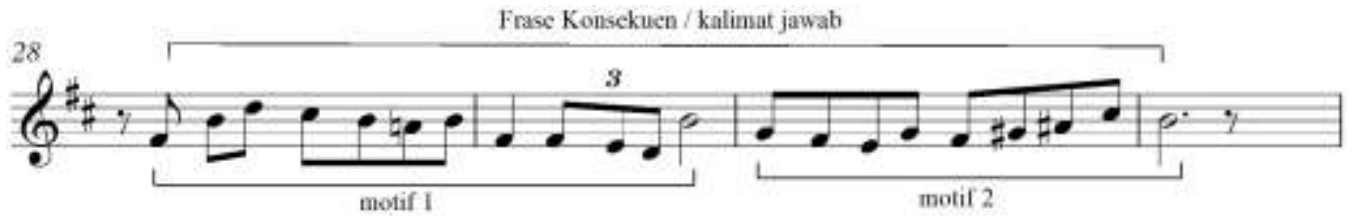

Notasi 15: Frase Konsekuen 
Keterangan motif 1 di atas pada bagian ini adalah motif ulangan harfiah. Untuk menjelaskan motif tersebut dapat dilihat gambar berikut.

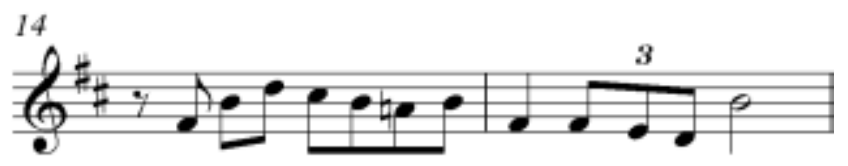

Notasi 16: Motif 1 frase konsekuen bagian A

Kemudian motif 2 pada frase konsekuen bagian ini merupakan pembesaran interval (augmentation of the ambitus) dari motif 2 frase konsekuen bagian A, untuk memperjelas motif pembesaran interval tersebut dapat dilihat pada gambar berikut.

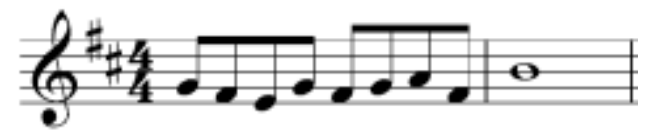

Notasi 17: Motif 2 frase konsekuen bagian A

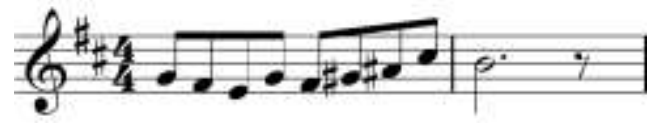

Gambar 18: Motif 2 frase konsekuen bagian A'

Motif 2 frase konsekuen bagian A' adalah pembesaran interval (augmentation of ambitus) dari motif 2 frase konsekuen bagian A. Adapun repetisi tentang bagian ini dapat dilihat pada gambar berikut.

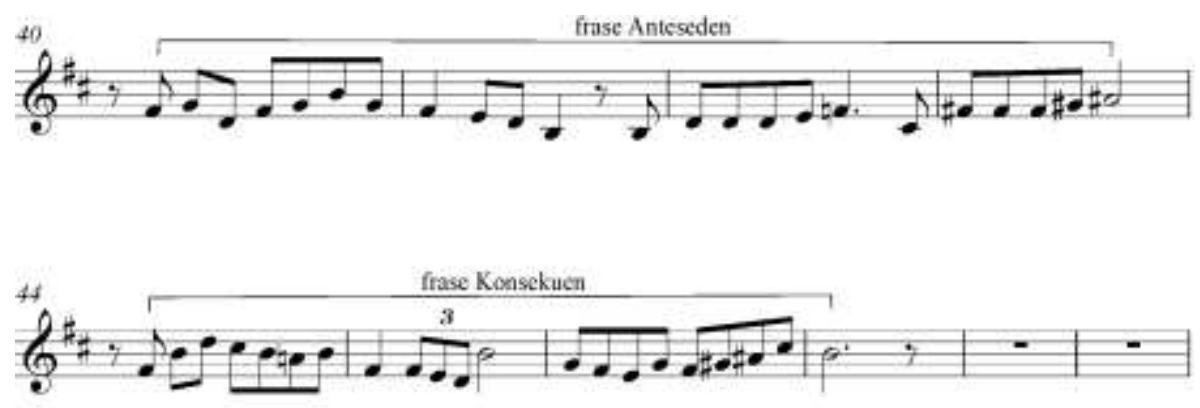

Notasi 19: repetisi bagian A'

Gambar di atas menunjukkan repetisi ini berawal dari birama 40 sampai birama 47 . Setelah penjelasan tentang bagian A'. Kemudian dilanjutkan dengan bagian B. 
4. Bagian B

Bagian B merupakan periode yang memiliki 2 frase yaitu frase anteseden dan frase konsekuen. Pada bagian ini di modulasi menjadi mayor dari tangga nada $D$ atau $\mathrm{B}=$ la menjadi tangga nada $\mathrm{B}$ mayor atau $\mathrm{B}=$ do dengan progress chord dapat dilihat pada gambar berikut.

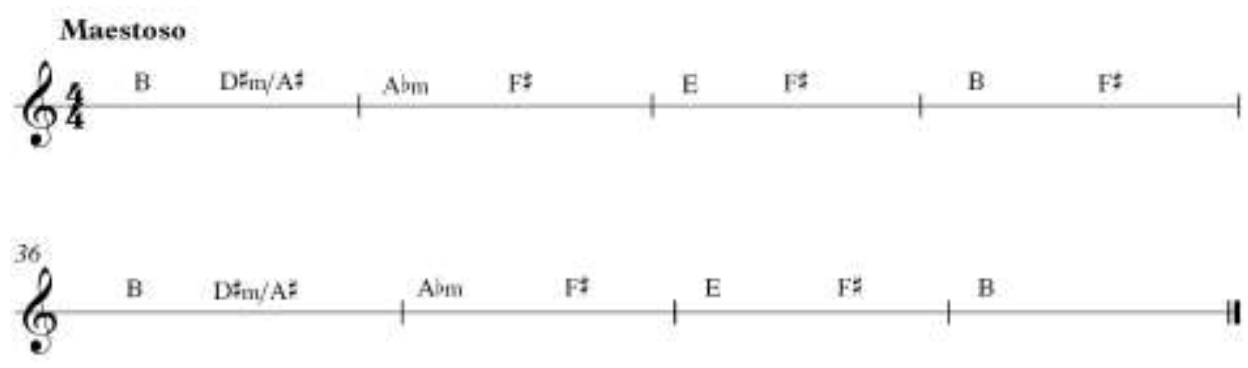

Notasi 20: Progress chord

Untuk memperjelas bagian B, frase tanya (anteseden) dan frase jawab (konsekuen) dapat diperhatikan gambar berikut.

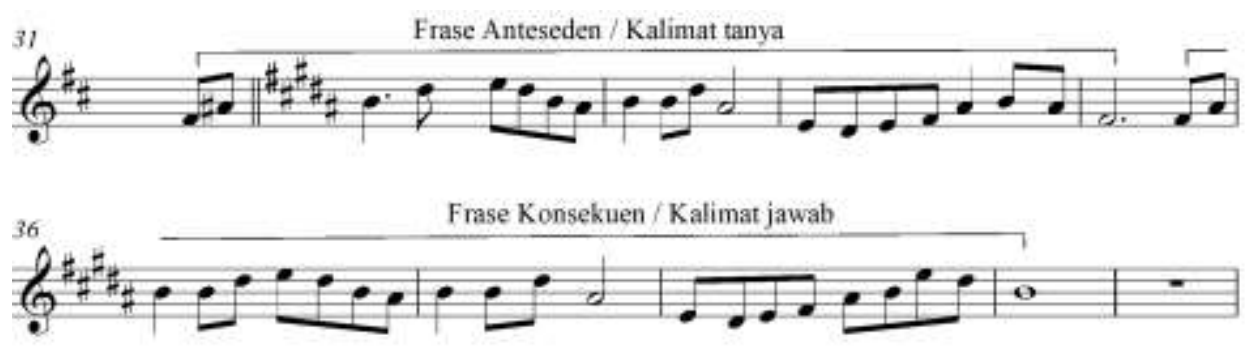

Notasi 21: Periode bagian B

Bagian ini terdiri dari dua frase yaitu frase anteseden dan frase konsekuen. Untuk memperjelas keterangan frase pada bagian ini dimulai dari frase anteseden.

\section{a. Frase Anteseden}

Frase pada bagian ini dimulai dari birama 31 ketukam empat sampai birama 35. Untuk memperjelas keterangan frase anteseden dapat dilihat pada gambar berikut :

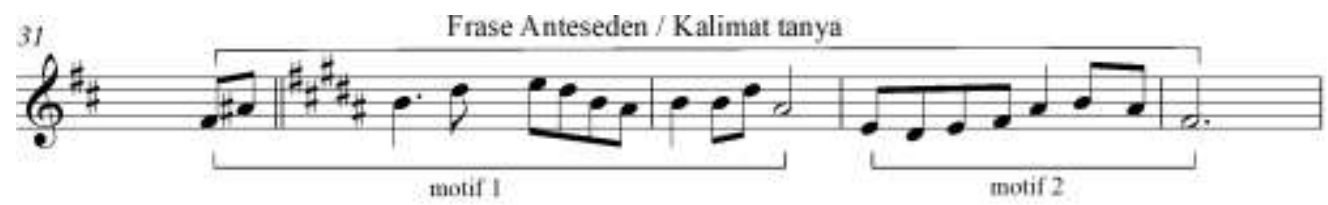

Notasi 22: Frase anteseden 
Dari gambar di atas pada frase tanya terdiri dari empat birama. Motif 2 merupakan motif pembalikan bebas dari motif 1 sebagai motif asli. Kemudian dilanjutkan dengan frase konsekuen bagian $\mathrm{B}$.

\section{b. Frase Konsekuen}

Frase pada bagian ini dimulai dari birama 36 sampai birama 39, jumlah seluruhnya adalah 4 birama. Untuk memperjelas keterangan frase konsekuen dapat dilihat gambar berikut.

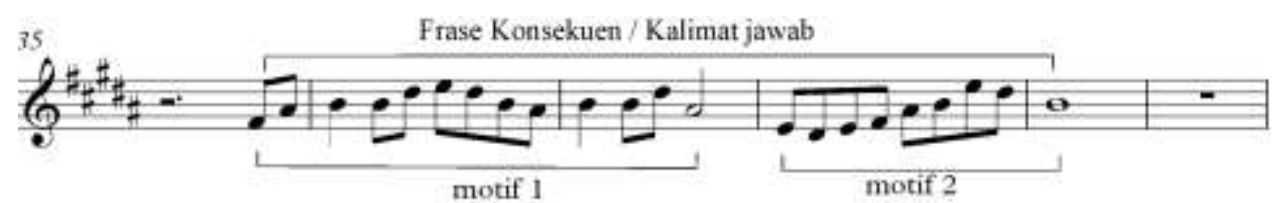

Notasi 23: Frase konsekuen

Motif 1 merupakan motif pemerkecilan nilai nada (diminuation of value) dari motif 1 frase anteseden. Untuk memperjelas pengulangan motif dapat dilihat pada gambar berikut.

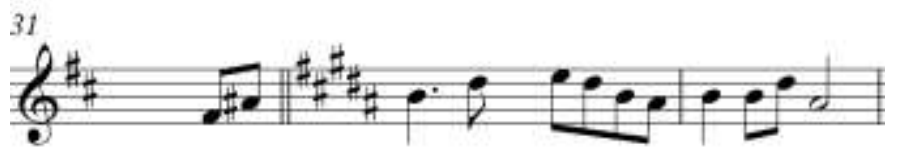

Notasi 24 A: Motif 1 frase anteseden bagian B

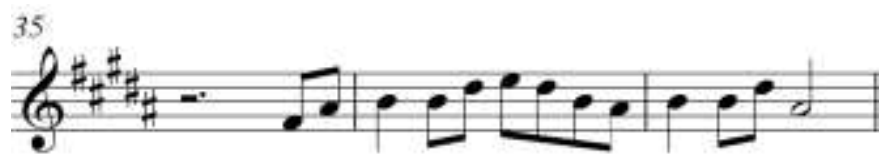

Notasi 24 B: Motif 1 frase konsekuen bagian B

Kemudian motif 2 frase konsekuen merupakan motif pembesaran interval (augmentation of ambitus). Untuk memperjelas pembesaran interval tersebut dapat dilihat gambar berikut.

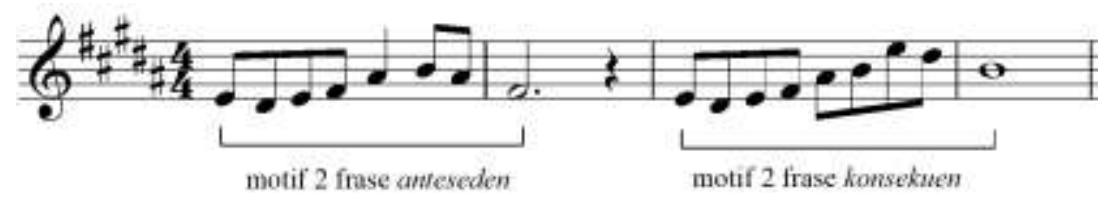

Notasi 25: Motif pembesaran interval (augmentation of ambitus)

Dari uraian motif diatas menunjukkan bahwa, motif 2 frase konsekuen adalah pembesaran interval (augmentation of ambitus) dari motif 2 frase anteseden.

Dari penguraian di atas yang menunjukkan bahwa dilihat dari bentuknya lagu ini memiliki tiga bagian yaitu A A' B. Bagian-bagian yang terdapat dalam lagu ini 
yaitu bagian A (ax), bagian A' (ax'), bagian B (by). Dari pernyataan tersebut terlihat lagu ini memiliki bentuk simetris, merupakan dua unsur saling melengkapi sehingga ukurannya sama, pertanyaan dengan empat birama di jawab dengan jawaban empat birama (Prier, 1996 : 21).

\section{Proses Pembuatan Lagu Ida Sang Sujati}

Lagu Ida Sang Sujati diciptakan untuk Album Bali Kumara Generasi tiga yang di launching di Ksirarnawa, Art Centre, Denpasar, Bali pada tanggal 12 Desember 2016. Proses pembuatan lagu yang dimulai dari saat I Komang Darmayuda menjadi juri di ajang Pesta Kesenian Bali (PKB) yang berlokasi di Gedung Terbuka Ardha Candra, dan terlintas bagaiamana cara agar masyarakat mengetahui penggagas Pesta kesenian Bali dan pendiri Art Centre yaitu berawal dari imajinasi terhadap sosok yang menginspirasi ditahun 80-an yaitu Prof. Ida Bagus Mantra, gubernur Bali yang menjabat dari tahun 1978-1988 sangat menginspirasi bagi I Komang Darmayuda pada eranya. Hal ini terbukti dengan kemurahan hati Prof. Ida Bagus Mantra yang pada saat itu menjabat sebagai gubernur menyumbangkan tanah dengan sukarela yang sekarang digunakan untuk Art Centre yang terletak di Jalan Nusa Indah, Denpasar, Bali untuk mempertahankan hidup kesenian di Bali. Sekaligus menjadi penggagas dan memprakarsai suatu wadah pesta rakyat, yang sampai sekarang disebut "Pesta Kesenian Bali" (PKB).

\section{Tahap Proses Peciptaan}

Tahapan pada proses penciptaan lagu Ida Sang Sujati dimulai dari pengerjaan progress chord dengan piano dikerjakan sendiri oleh I Komang Darmayuda dan dikemas menjadi partitur di Studionya yang berlokasi di kediaman beliau sendiri. Berikut progress chord saat proses pembuatan lagu Ida Sang Sujati (gambar 4.33) pada pembuatan awal lagu ini di awali dengan nada dasar $\mathrm{C}$ atau $A=$ la dengan tempo maestoso (berasal dari bahasa Italia yang berarti layak, anggun). Dapat dilihat bahwa transisi terjadi pada birama ke sembilan hingga empat belas. Modulasi yang terjadi pada birama 17 adalah Ref. Pada bagian reff nada dasar di modulasi menjadi $\mathrm{A}=\mathrm{do}$ atau dari tangga nada minor ke mayor.

Setelah pengerjaan chord dengan piano, barulah I Komang Darmayuda membuat melodi. Melodi itu seperti imajinasi yang pertama kali hanya dialami oleh yang memiliki imajinasi, yaitu komponis lagu itu (Ardini, 2017 : 47). Melodi memiliki 
bentuk dan struktur yang sama dengan syair lagu. Untuk lebih jelas terkait melodi pada lagu Ida Sang Sujati, berikut adalah proses penuangan melodi pada chord yang telah dibuat. (lampiran gambar 29). Pada proses lirik lagu ini menggunakan bahasa Bali alus yang berarti lagu ini berperan melestarikan bahasa dan budaya Bali. pengertian dari lirik "Ida" baris pertama menggambarkan tokoh Prof. Ida Bagus Mantra. Walaupun Sempat terkendala dalam pengerjaan lirik karena tidak adanya buku pada saat itu dan tidak ada wawancara sama sekali tidak mematahkan semangat beliau dalam bekerja, hanya mendapatkan inspirasi lirik dari cerita Ngurah Ardjana (Pencipta lagu "Serangan Pulau Kenangan") dengan menyusun kata perkata yang jujur dan berimajinasi menikmati bagaimana kemurnian hati dan kerendahan hati Prof. Ida Bagus Mantra sebagai gubernur.

Berikut adalah secara keseluruhan mengenai partitur asli yang diperoleh langsung dari penciptanya, yaitu I Komang Darmayuda (lihat gambar 30). Dalam proses pembuatan lagu, judul adalah hal yang paling penting, sebelumnya lagu ini diberi judul Prof. Ida Bagus Mantra, namun, menurut I Komang Darmayuda terkadang ada orang yang tidak ingin di ketahui maka beliau memutuskan untuk judul adalah Ida Sang Sujati .

\section{Proses Rekaman}

Dalam tahap proses pembuatan ini, I Komang Darmayuda tidak bekerja sendirian. Setelah itu, partitur yang telah siap dengan rekaman suara I Komang Darmayuda untuk di proses kepada pemusik untuk di aransemen dengan orkestrasi, harmoni dan instrumen yang dibantu oleh rekannya sewaktu sekolah di SMM, Dewa Sujana. Setelah musik yang dibuat dalam bentuk aransemen termasuk harmoni, orkestrasi dan lain lain, barulah melakukan take vocal lagu ini yang di bantu oleh Wiwit Setiawan.

Penyanyi dari Bali Kumara yang menyanyikan lagu Ida Sang Sujati ini adalah Nita Purnama. Untuk mengindari ketidakcocokan I Komang Darmayuda memang sangat selektif kepada anak-anak Bali Kumara yang akan membawakan lagu ciptaannya. Pemilihan para penyanyi untuk lagu ciptaan I Komang Darmayuda tidak terlepas faktor-faktor yang perlu diperhatikan dalam menginterpretasi lagu, antara lain tema lagu, unsur-unsur musik (tanda tempo, tanda dinamik, tanda ekspresi, irama, dan birama), pesan dan kesan yang disampaikan, kesulitan-kesulitan lagu, gaya dan klimaks lagu (Ardini, 2014: 44). Dengan begitu, Nita Purnama dapat 
menguasai faktor-faktor tersebut dalam menginterpretasi lagu Ida Sang Sujati sehingga kesan dan pesan pada lagu tersebut dapat tersampaikan.

Lagu ini sangat berkesan bagi Nita Purnama Sari dan ia merasa bangga dapat dipercaya untuk menyanyikan lagu penuh keagungan, dan berkeinginan untuk kedepannya lagu ini bisa dijadikan motivasi kepada penyanyi lain. Dalam pengambilan gambar untuk keperluan syuting, video klip lagu Ida Sang Sujati ini mengambil latar di Art Centre, Denpasar. Dengan adanya dokumen yang diunggah ke youtube diharapkan lagu ini bukan orang Bali saja yang dapat mengenang kiprah sosok gubernur Bali namun seluruh Indonesia, supaya lagu tersebut bisa dirasakan oleh masyarakat luas.

\section{Launching}

Lagu Ida Sang Sujati dalam Album Bali Kumara Generasi tiga, launching di Ksirarnawa, Art Centre, Denpasar, Bali pada tanggal 12 Desember 2016. Arti launching adalah bentuk kegiatan dalam hubungan masyarakat yang menjangkau dan menarik minat masyarakat sasaran (Amstrong, 2008: 171). Pada proses launching I Komang Darmayuda tidak bekerja sendirian, setelah pengerjaan rekaman selesai para orang tua dari penyanyi album Bali Kumara berkumpul pada sanggar Cressendo dan berdiskusi untuk memutuskan album Bali Kumara yang akan launching di tahun 2016. Hal ini sama seperti penjelasan sebelumnya mengenai lahirnya Bali Kumara, yaitu para orang tua lah yang menyatukan ide dan mengumpulkan modal dari membayar lagu, membuat musik, video klip, kostum dan cetak DVD (Digital Versatile Disc). Tidak hanya berhenti pada launching saja, beberapa minggu setelah kegiatan tersebut, sanggar Cressendo mengadakan lomba menyanyi lagu-lagu di album Bali Kumara. Peserta lomba sampai ke plosok-plosok kabupaten di Bali. hal tersebut berarti antusias yang sangat besar bagi album Bali Kumara. Semakin banyak orang yang terlibat seperti membeli album, mengunduh video, menyanyikan lagu dan mengikuti lomba, secara tidak langsung semakin banyak orang yang turut serta terlibat dalam usaha pelestarian seni dan budaya.

\section{Makna Musikal Lagu Ida Sang Sujati}

Pada zaman modern saat ini kesenian cenderung dilihat sebagai sumber hiburan semata daripada sebagai wahana pencerahan batin. Padahal jika dicermati, sebuah bentuk karya seni, yakni dalam hal ini berupa lagu album Bali Kumara, 
amatlah sarat dengan kandungan makna yang sangat mendalam sehingga dapat digunakan sebagai cerminan dalam bertingkah laku.

Setelah mencermati bait demi bait diperoleh tiga makna yang terkandung didalamnya, yaitu (1) makna pendidikan, (2) makna sosial budaya, (3) makna kepemimpinan.

Seperti yang telah dikemukakan yang sesuai dengan Undang-Undang No. 20 Tahun 2003 pasal 1 ayat 1 tentang Sistem Pendidikan Nasional, bahwa pendidikan adalah usaha sadar dan terencana untuk mewujudkan suasana belajar dan proses pembelajaran agar peserta didik secara aktif mengembangkan potensi dan keterampilan yang diperlukan dirinya, masyarakat, bangsa, dan negara. Hal ini mengandung suatu pengertian bahwa pendidikan memegang peranan penting dalam kehidupan manusia yang berbudaya, terutama dalam upaya mengembangkan kepribadiannya. Oleh karena itu, upaya tersebut perlu dilakukan sejak usia dini, baik melalui proses pembelajaran secara formal, non formal, atau informal.

Berdasarkan uraian tersebut, maka jelas di dalamnya terkandung makna pendidikan tentang pelestarian budaya Bali. Melalui lirik lagu tersebut pengarang memberikan isyarat senantiasa menjaga eksistensi seni budaya Bali. sebagai pendukung budaya Bali, hendaknya memiliki komitmen bersama untuk terus berupaya mengembangkan serta melestarikan produk seni budaya dalam bentuk kesenian. Belajar sambil bernyanyi juga adalah salah satu proses pembelajaran informal yang sangat ideal untuk diterapkan dalam upaya pembentukan kepribadian yang mandiri.

Setiap karya seni mencerminkan tempat seni itu diciptakan. Sebuah karya seni ada karena seorang seniman menciptakannya. Seniman berasal dan hidup dari masyarakat tertentu (Sumardjo, 2000: 233). Seorang seniman tidak bisa hidup sendiri, sehingga memerlukan orang lain sebagai penikmat sekaligus pendukung demi keberlangsungan hasil karya seninya. Oleh karena sebelum menjadi seorang seniman tentu dirinya berawal dari sebagai anggota masyarakat yang mendapatkan pengalaman dan belajar melalui kehidupan serta budaya masyarakat tempat ia tinggal (Suarningsih, $2004:$ 180).

Lagu Ida Sang Sujati menggambarkan kondisi sosial budaya Bali yang sangat kaya dengan kekayaan budaya warisan. Seperti yang terkandung dalam 
penggalan lirik yang menggambarkan taman budaya yakni Art Centre sebagai salah satu warisan dari Prof. Ida Bagus Mantra, yang hingga kini tempat tersebut mempertahankan hidup kesenian di Bali. Lagu ini memberikan makna budaya yang adiluhung. sebagai upaya pelestarian, hendaknya secara bersama-sama mempunyai suatu cita-cita dan komitmen yang sama untuk mempertahankan, melestarikan, serta sekaligus mengembangkan eksistensi budaya Bali ke depan. Kekayaan seni budaya Bali yang sudah terkenal di seluruh dunia perlu dipertahankan agar tidak sirna ditelan zaman.

Dalam kamus besar Bahasa Indonesia, istilah pemimpin diartikan sebagai pemuka, penuntun (pemberi contoh) atau petunjuk jalan. Jadi secara fisik pemimpin itu berada di depan. Tetapi pada hakikatnya, dimanapun tempatnya, seseorang dapat menjadi pemimpin dalam memberikan pimpinan. Sedangkan menurut Anoraga tahun 2014, dalam praktek organisasi, kata memimpin mengandung konotasi, menggerakkan, mengarahkan, membimbing, melindungi, membina, memberikan teladan, memberikan dorongan, dan memberikan bantuan.

Hal di atas sesuai dengan lagu Ida Sang Sujati, dimana lagu ini mengusung tema Prof. Ida Bagus Mantra yang memimpin Bali sebagai gubernur (1978-1988) yang sangat menginspirasi karena membangun fisik dan pembangunan mental identitas masyarakat Bali. Makna kepemimpinan seperti dalam lirik lda sekadi tarune kukuh ageng yang memiliki perumpamaan seperti pohon taru yang besar dan kuat melindungi rakyat Bali. Lirik di atas juga mencerminkan bahwa masa kepemimpinan Prof. Ida Bagus Mantra, beliau menyumbangkan tanah dengan sukarela guna menampung hasil karya cipta, seni dan aspirasi berkesenian serta apresiasi seni dan budaya masyarakat. Dengan begitu beliau sebagai pemimpin Bali pada masa itu memberikan contoh menata Bali serta menggerakkan seni dan agama, juga memberi kesan tentang keinginan pemimpin, sehingga dapat menimbulkan kepatuhan, rasa hormat, loyalitas dan kerjasama.

\section{SIMPULAN}

Lagu Ida Sang Sujati adalah salah satu nilai yang tidak diketahui oleh anakanak jika tidak diungkapkan lewat lagu pada album Bali Kumara sebagai bentuk pemertahanan budaya Bali karena mengandung pesan mendalam dalam usaha pelestarian budaya yang terinspirasi dari kepemimpinan gubernur Bali yang pertama 
yaitu Prof. Ida Bagus Mantra. Selain itu lagu-lagu bertemakan seni dan budaya Bali yang dinyanyikan oleh anak-anak yang tergabung dalam Bali Kumara tersebut juga merupakan alat efektif sebagai media pemertahanan budaya dan bahasa Bali karena mengandung pesan yang mendalam dalam usaha pelestarian seni, budaya dan bahasa Bali. Hingga kini lagu Ida Sang Sujati masih tetap menjadi lagu pilihan dalam ajang perlombaan menyanyi di Bali, dan berharap agar lagu ini tetap hidup keberadaannya supaya penerapan memahami kearifan lokal terhadap anak-anak bisa diserap langsung.

Lagu Ida Sang Sujati ini menggunakan tanda mula dua kress atau $B=l a$, kemudian di modulasi menjadi lima kress atau $\mathrm{B}=\mathrm{do}$, dengan tempo maestoso (70MM) yang berarti lambat dan penuh keagungan. Dengan sukat $4 / 4$ yang berarti bahwa dalam satu birama terdapat empat ketukan, lagu ini berdurasi 4: 59 detik jika dilihat bentuknya terdiri dari tiga bagian yaitu A A' B, bagian A (ax), bagian A' (ax'), bagian $B$ (by). Komposisi ini diawali dengan introduksi dengan bentuk lagu simetris.

Proses pembuatan lagu Ida Sang Sujati diawali dari imajinasi I Komang Darmayuda terhadap sosok yang menginspirasi di tahun 80 -an yaitu Prof. Ida Bagus Mantra. Dengan tahap pembuatan yaitu pengerjaan chord yang disusul penyusunan melodi kemudian lirik yang dikerjakan sendiri oleh I Komang Darmayuda. Setelah itu proses rekaman yang dinyanyikan langsung oleh Nita Purnama Sari sebagai penyanyi Bali Kumara generasi ke-3, dilanjutkan dengan pembuatan video klip yang di unggah ke youtube sebagai bentuk kenangan agar lagu ini dapat dirasakan oleh masyarakat luas yang berlatar tempat di Art Centre. Setelah semua selesai lagu Ida Sang Sujati launching dengan lagu lainnya dalam album Bali Kumara yang di selenggarakan di Ksirarnawa, Art Centre pada tanggal 12 Desember 2016. Tidak hanya berhenti di launching, namun seminggu setelah kegiatan tersebut lagu yang terdapat pada album Bali Kumara dijadikan lagu pilihan dalam lomba menyanyi, semakin banyak yang membeli album, menonton video, menyanyikan lagu dan mengikuti lomba, secara tidak langsung semakin banyak yang terlibat dalam usaha pelestarian seni dan budaya.

Setelah mencermati lirik lagu Ida Sang Sujati, maka dapat dikemukakan bahwa makna yang terkandung dalam lagu tetap tersirat. Adapun makna yang berhasil diungkap melalui lirik lagunya adalah (1) makna pendidikan, (2) makna sosial, (3) makna kepemimpinan. 


\section{DAFTAR PUSTAKA}

Anoraga, Panji. 2009. Psikologi Kerja. Jakarta: Rineka Cipta.

Ardini, Ni Wayan. 2017. Instrumen Mayor I Vocal. Denpasar: Diktat Perkuliahan, Fakultas Seni Pertunjukan Institut Seni Indonesia Denpasar.

Ardini, Ni Wayan. 2014. "Industrialisasi Musik Pop Bali : Ideologi, Kepentingan, dan Praktikanya." Disertasi Program Pasca Sarjana Universitas Udayana. Denpasar : Universitas Udayana.

.2018. "Balinese Pop Music: An Industrialization Era". Journal of Music Science, Technology, and Industry, 1(1), 129-138. https: //doi.org/10.31091/jomsti.v1i1.509, https: //jurnal.isidps.ac.id/index.php/jomsti/article/view/509

Asty, Putu Ayu. 2017. "Bali Kumara : Upaya Pelestarian Bahasa dan Budaya Bali oleh Anak-anak dan Remaja Bali”. Prosiding Seminar Nasional Bahasa Ibu ke X. Denpasar, Fakultas Ilmu Budaya Universitas Udayana.

Banoe, Pono. 2003. Kamus Musik. Yogyakarta: Kanisius Yogyakarta

Djelantik, A.A.M. 1990. Pengantar Dasar IImu Estetika, Jilid 2, Estetika Instrumental. Sekolah Tinggi Seni Indonesia Denpasar. Penerbit : Institut Seni Indonesia Denpasar.

Edmund, Karl. 1996. IImu Bentuk Musik. Yogyakarta : Pusat Liturgi Yogyakarta

Giri, Ariasa. 2017. "Pelestarian Bahasa, Aksara, dan Sastra Bali melalui Pengoptimalan Tripusat Pendidikan." Jurnal Purwadita Volume 1 No.1. Penerbit : STAHN Mpu Kuturan Singaraja.

Ariesta, I. M. J., Ardini, N. W., Darmayuda, I. K., \& Sumerjana, K. .2018. "Analisis Bentuk dan Struktur Komposisi "Morning Happiness" Gus Teja. Journal of Music Science, Technology, and Industry, 1(1), 35-72. https: //doi.org/10.31091/jomsti.v1i1.504 https: //jurnal.isidps.ac.id/index.php/jomsti/article/view/504.

Suarningsih, Ni Made. 2004. "Lagu Pop Bali Anak-anak dalam Kajian Budaya”. Tesis Program Pasca Sarjana Universitas Udayana. Denpasar : Universitas Udayana.

Sumardjo, Jacob. 2000. Filsafat Seni. Bandung: ITB. 